\title{
The grape viticulture production cycle as a biomimicry concept: finding solutions in the built environment
}

\author{
S. Al-Zahabi \& H. Taleb \\ Sustainable Design of the Built Environment, \\ British University in Dubai, UAE
}

\begin{abstract}
It is important to understand biomimicry from a different perspective, other than a natural concept, model, measure or mentor. Biomimicry illustrates the environmental adaptation of a complete natural plant cycle, "grape viticulture production", considered as a sensitive process that requires special care for a healthy production. This process is mentioned in detail in the Holy Qur'an, "Surat Al Kahf" Ayah 32 and is noted as one of Qur'an ayah's miracles. This research paper will present and analyze the natural concept of grape cultivation by studying and visualizing the anatomy of grapes; soil, temperature, natural light, water, wind and surrounding elements, such as palm trees. Natural concepts will be retrieved to a parallel environmental strategy design and then analyzed to prove design success. Using analysis software, five environmental strategies will be tested: daylight factors, shading elements, building the thermal envelope, air movement and solar energy. In conclusion, the final comparisons will be illustrated in a scientific table, illustrating the differences between the existing and the proposed, using analytical software - Autodesk Ecotect - in addition to manual calculation strategies. Upgrading the selected design strategies may lead to a $100 \%$ passive design and will achieve a sustainable, calm and healthy environment where the function of the Mosque can truly be achieved.
\end{abstract}

Keywords: biomimicry, grape viticulture, environmental strategies, daylight factor, thermal envelope, solar energy, UAE. 


\section{Introduction}

Biomimicry can be defined and expressed in various ways, not only as a natural concept, but it can also act as a natural model, a natural measure, and as a natural mentor [1]. Environmental adaptations is the focal points of this research paper that will lead and elaborate on focused implementation to be addressed on a design methods of specific case. Grapes viticulture is the selected natural concept, which the suggested environmental strategies are derived from.

\section{Methodology}

Based on the selected natural concept anatomy, this research studies and develops by the environmental growth and climatic strategies of its surroundings. This report is proposing a new implementation of biomimicry to introduce better sustainable solutions expressed through conceptual critical design methods. Using Ecotect simulation software, the suggested enhancements on the existing site are tested, then a comparison of the before and after situations (existing and proposed) are provided.

\section{Natural concept}

Grapes are one of the oldest plants known to human beings; they are not only used as a source of food but also as a drink, meditation and a popular climbing plant. Plants in general and grapes specifically are known for their need of highly suitable environments in order to grow and reproduce, this is caused by their sensitivity characteristics.

The study of grapes production is called 'viticulture'. One of the most important elements that determine grape production is soil. Temperature, light, humidity and wind also play a big role in soil and production.

\subsection{Grape production: scientific miracle in the Holy Quran}

The Holy Quran summarizes the ideal environment for planting grapes in "Surat Al Kahf" Ayah 32, saying:

Ayah translation, by Khan and Al Hilali, The Noble Quran-In The English Language [2]:

32. And put forward to them the example of two men: unto one of them we had given two gardens of grapes, and we had surrounded both with date palms; and had put between them green crops.

Recent research endorses the above mentioned Ayahs of being a significant scientific miracle in the Quran that briefly presents an ideal environmental climate for viticulture; the distribution of the wind, light, humidity, water and temperature.

Planting seeds needs special care and specific environmental conditions such as warmth, sunlight, air, soil and water that have a direct effect must be distributed and used efficiently. 


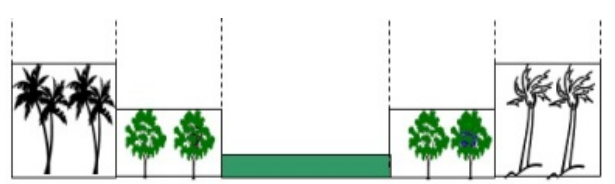

Figure 1: Viticulture, ideal distribution, miracles of the Quran (palm trees, grape trees and plants).

When grape seeds start to grow, small stems start to appear on the ground, while the roots start to spread underground. In the presence of warm sunlight and water, stems continue to grow and produce grape leaves. The leaves sleep in the absence of sunlight at the end of the summer season. Grape vines are very soft and not like the woody trunk of a tree, able to carry up in the air, vines need the support of rods to be raised high and be able to absorb sunlight [3].

As pictured in Ayah 32, figure 1 illustrates the ideal farm plant division from the highest plants to the lowest height plantation, allowing the air to flow in between. Shading also plays a big role; created by the shadow of tall plants (palm trees) on the short plants (grapes).

\section{Case study location and function}

The selected base case is Al-Ali Mosque located in Barsha residential area, Dubai, UAE, having a total area of 2109 square meters, including prayer rooms, classrooms, and washrooms. The main focus will be the male and female prayer area [4]. Al-Ali Mosque is active five times a day during prayer times and visitors range between five and twenty five per cent for prayer except for Friday where the range increases from fifty to one hundred and fifty for the Al Juma' $a$ prayer. Energy is consumed mainly by the usage of lighting, speakers and HVAC.

There are four minarets (lighthouses) on each corner. The minarets are not just a decorative element, they are used to provide a vantage point for a person to go up and call to prayer. Figure 2 illustrates the interior and exterior images on site.
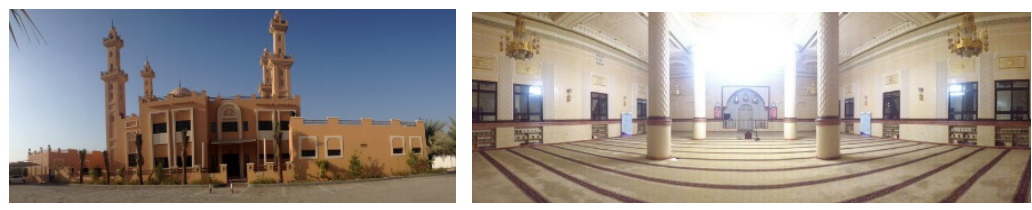

Figure 2: Exiting base-case, exterior/interior view, Al-Ali Mosque.

\section{Climate data analysis}

\subsection{Temperature}

Dubai is known for its high temperature, the average temperature ranges between 24 and 41 degrees Celsius. Eight months of the year is a summer season where 
the temperature increases above 30 degrees, while only four months of the year count as winter where the temperature decreases below 30 degrees.

\subsection{Wind analysis}

Average wind analysis frequency in Dubai concentrates on the northwest with the highest frequency, decreasing in the eastern direction and fading on southern direction. Based on the analysis graphs from Autodesk Ecotect, figure 3 illustrates a light blue shade for high wind frequency and dark blue for low frequency, and mid-temperature in the orange range, and yellow for hot wind temperature.
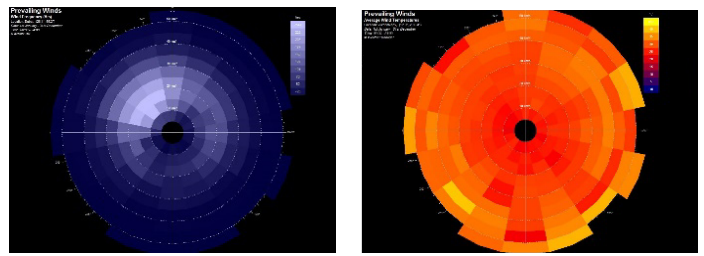

Figure 3: Prevailing winds/wind analysis, yearly, Dubai, UAE.

\subsection{Monthly duration average}

Dubai comfort zone ranges between 20 and 30 degrees. The temperature starts to rise during the months of May to September, requiring cooling and ventilation strategies to offer better indoor quality, comfort and reduce temperature.

\section{Biometric strategies: analysis and discussion}

\subsection{Environmental strategies and design methods}

Understanding grape plantation climate strategies and the climate data of the selected base-case building. Table 1 below briefly compares environmental strategies and proposed design methods.

\subsection{Comparison between existing building analysis and characteristics of grape production and strategy implementation}

Based on the natural concept's characteristics and specialities, five selected strategies will be tested and analysed in this paper. Solutions of each implemented method will be compared by a related natural source. Exploring the differences between the existing and proposed depending on analysis software Autodesk Ecotect - and/or by using other manual calculations and methods.

\subsubsection{Strategy 1: daylight factors}

All living things need certain amount of sunlight to grow and survive. Light is one important factor for an ecosystem. The reason grape branches must be 
supported by rods high from ground level is to increase the possibility of collecting the required amount of sunrays, by its circular shape.

Table 1: Environmental strategies vs. design method comparison table.

\begin{tabular}{|c|c|c|c|}
\hline & & Environmental strategies & Design methods \\
\hline 1 & $\begin{array}{l}\text { Daylight } \\
\text { factors }\end{array}$ & $\begin{array}{l}\text { Amount of sunlight needed for grape } \\
\text { growth and healthy production (grape } \\
\text { cylindrical shape) }\end{array}$ & $\begin{array}{l}\text { Changing existing sky domes } \\
\text { to double glazed domes and } \\
\text { increasing their quantity }\end{array}$ \\
\hline 2 & $\begin{array}{l}\text { Shading } \\
\text { elements }\end{array}$ & $\begin{array}{l}\text { Palm trees surrounding the grape } \\
\text { trees } \\
\text { Shade of grapes leaves }\end{array}$ & $\begin{array}{l}\text { Columns (influenced by palm } \\
\text { trees) }\end{array}$ \\
\hline 3 & $\begin{array}{l}\text { Building } \\
\text { thermal } \\
\text { performance }\end{array}$ & $\begin{array}{l}\text { Soil ingredient (rich with } \\
\text { nutrients/water } \\
8-10 \text { cell wall layers, outer later } \\
\text { covered with wax-like waterproof } \\
\text { skin }\end{array}$ & $\begin{array}{l}\text { Under floor cooling system } \\
\text { Usage of Thasos Marble (heat } \\
\text { and moisture absorber) }\end{array}$ \\
\hline 4 & $\begin{array}{l}\text { Air movement } \\
\text { controlling and } \\
\text { ventilation }\end{array}$ & Palm trees surroundings & $\begin{array}{l}\text { Columns (wind stoppers) } \\
\text { Minaret (wind towers) } \\
\text { Louvre windows }\end{array}$ \\
\hline 5 & $\begin{array}{l}\text { Direct solar } \\
\text { rays destitution }\end{array}$ & $\begin{array}{l}\text { Grape vines branches and fastens } \\
\text { itself high from the ground to absorb } \\
\text { sunlight rays }\end{array}$ & Solar panels on roof top \\
\hline
\end{tabular}

6.2.1.1 Monthly/hourly sun path diagram Analysing the selected site, it is noticeable that the amount of sunlight gained is limited. Main window opening are on north side, and main entrance door blocks east/west directions. Only two opening are in the south direction. Testing in one of the hottest months in summer (August), at midday, all sides are shaded, excluding the south side, which the female prayer room is blocking; allowing poor sunlight to pass through two windows only.

In conclusion, the most exposed layer to sunlight in the male prayer area is the rooftop, which allows a good amount of sunlight to pass through. It is built in a residential area with a two storey maximum limit for houses, so no tall building or elements cover it. Figure 4 shows the shade at three different times in a day, almost all figures give poor lighting.

6.2.1.2 Scientific comparison: strategy 1 Strategy 1 will increase poor daylight factor in male prayer area by demolishing existing sky dome and replacing them with larger number of double full-glazed sky domes. Resulting in high exposure of sunlight, which will reduce the usage of electric power in the daytime by $60 \%$.

The figures below compare existing and proposed building model daylight illumines and the percentage of improvement. In the existing building, figure 5(a) illustrates poor light factor because of the closed ceiling and existence of only two windows on the south side. In the proposed design, figure 5(b) shows satisfaction of daylight by adding double-glazed domes. 


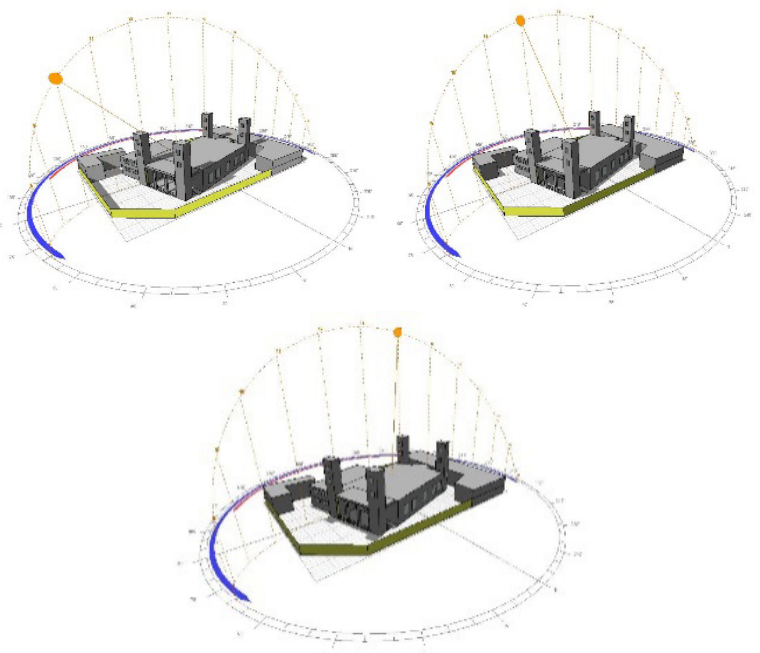

Figure 4: Al-Ali Mosque model, Sun Orientation, 10AM, 12PM, $2 \mathrm{PM}$.

(a)
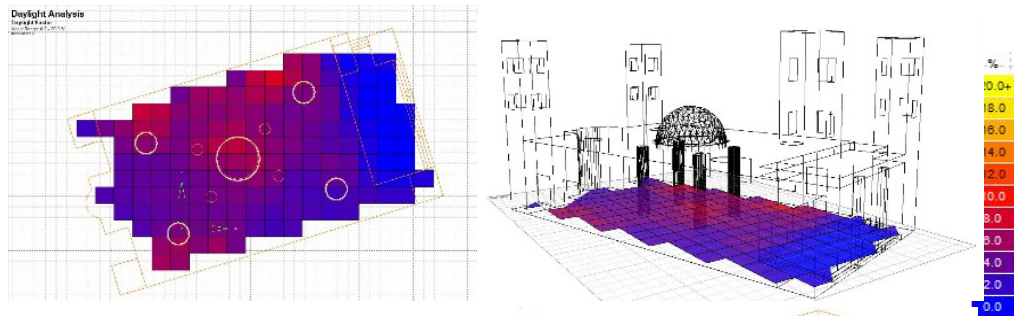

(b)
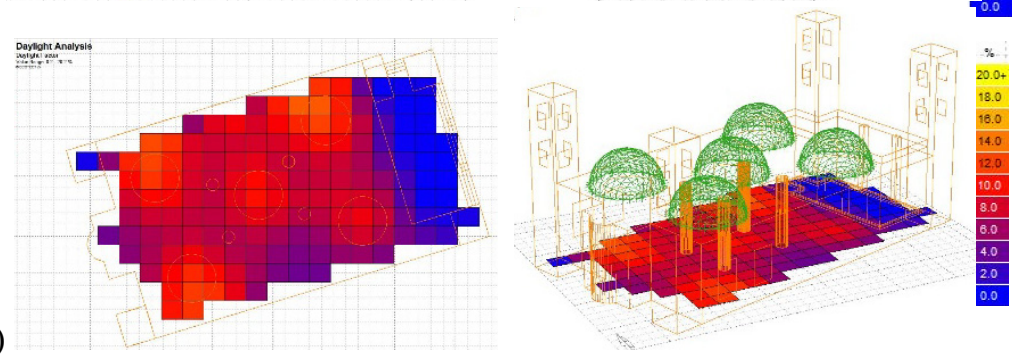

Figure 5: Existing/proposed design analysis, daylight factor.

\subsubsection{Strategy 2: shading elements}

Regardless of the importance of light needed for grape production, grapes are so sensitive that an increase in sunlight may harm their skin directly and end up spoiling them. God created grape leaves side by side to shade and balance the sunlight they are absorbing; he also mentioned the importance of surrounding them with palm trees for shade and wind circulation. 
6.2.2.1 Solar rays projection Solar ray direction depends on the month (season), day and time. In winter solar rays are lower than in summer, where the rays mostly hit the north direction. In summer, the solar rays hit from a higher level, In contrast, summer hot months; solar ray hits from a higher angle, exposing direct hot solar rays at an approximate of 80 degree from earth level, exposing direct rays from east to west and strong rays on south side, which also allows a narrow shade from north direction.

6.2.2.2 Scientific comparison of strategy Inspired from the grape production climate and surrounding elements (figure 6); illustrate shading design strategy influenced by natural concept of palm trees surrounding grapes, allowing indirect shade on the building. Design help maintain better building envelope temperature, and surrounding direct heat absorbance.

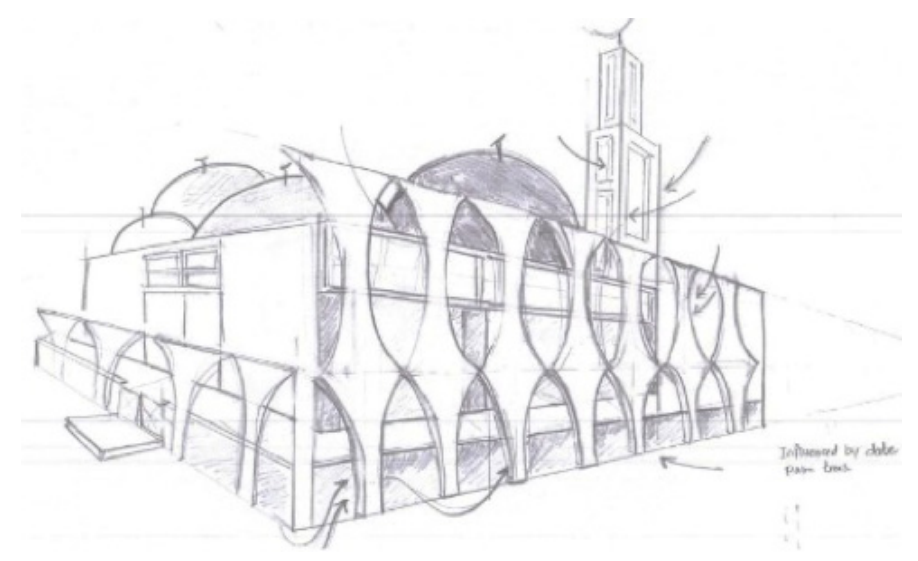

Figure 6: Author sketch, shading design elements, exterior façade, Mosque.

Application of long vertical building elements will enhance high comfortable light and shade system to protect the building interior and exterior, and also satisfy building with enough daylight factor in the central area (sky domes).

As a conclusion, below is the comparison between grapes' natural design and exiting design model that determines the amount of shade gained in both winter and summer months. Figures 7 show more integrity and shade balance for both the indoor and outdoor areas of the men's prayer area, as per the amount gained by the sensitive grapes. Nevertheless keeping the roof exposed to sunlight to allow sky domes to distribute indoor light efficiently.

\subsubsection{Strategy 3: thermal performance}

Focusing on the importance of soil to the sustainable growth of grapes, soil must be well drained to cool plants roots and supply water to grapes via their stems. It is hard to obtain it from its waterproof wax-like outer skin. Using water-cooling pipes underground and heat/moisture resistant marble would give users' bare feet (prayer) an ideal comfort and body temperature. 

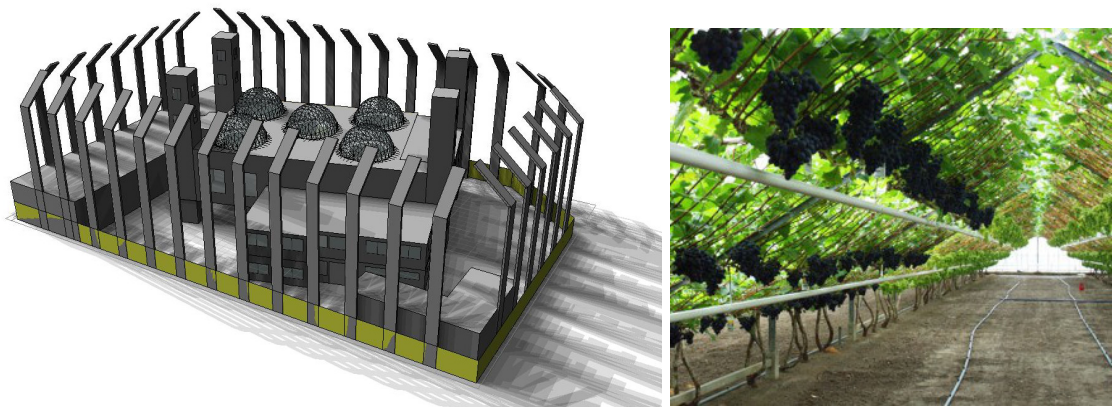

Figure 7: Shadow range (relative to grapes), August, midday.

Human feet, skin and nerves are sensitive and considered one of the most effective body parts in determining body heat. Cooling human bare feet in hot weather initiates a decrease in human body temperature. Therefore Thossas marble is used to promote the below points [6], and share similar contact with users; 1 - high reflectance of sunbeams, 2 - heat absorbance, 3 - white colour, which gives a white coldness and alleviation from heat surface.

6.2.3.1 Scientific comparison of strategy 3 Comparing proposed and existing envelops building material; existing building is built from concrete suspended ceiling and dome, concrete floor carpet finish, concrete block paint finished walls, with standard single glazed windows.

In contrast, the proposed envelop will show major changes that will enhance better insulation elements including water pipes, Thasos marble, and double glazing.

Table 2 explains in detail the comparison between each element in proposed and existing building, and numerical reading of their U-value. Proposed elements show decrease in U-value measuring as an improvement of building insulation from thermal heat and climatic changes.

Table 2: $\quad$ Model U-value, material assignment.

\begin{tabular}{|c|c|c|c|c|c|}
\hline & Roof/ceiling & & Floor & Walls & Windows \\
\hline $\begin{array}{l}\text { Existing } \\
\text { building } \\
\text { envelope }\end{array}$ & $\begin{array}{l}\text { Suspended } \\
\text { concrete } \\
\text { ceiling }\end{array}$ & $\begin{array}{l}\text { Concrete } \\
\text { dome, small } \\
\text { glass } \\
\text { windows }\end{array}$ & $\begin{array}{l}\text { Concrete floor, } \\
\text { carpet finish }\end{array}$ & $\begin{array}{l}\text { Concrete } \\
\text { blocks, paint } \\
\text { finish }\end{array}$ & $\begin{array}{l}\text { Single glazed } \\
\text { aluminum } \\
\text { frame }\end{array}$ \\
\hline U-value & $\begin{array}{l}2.560 \\
\mathrm{~W} / \mathrm{m}^{2} . \mathrm{K}\end{array}$ & $\begin{array}{l}3.100 \\
\mathrm{~W} / \mathrm{m}^{2} . \mathrm{K}\end{array}$ & $2.560 \mathrm{~W} / \mathrm{m}^{2} . \mathrm{K}$ & $1.800 \mathrm{~W} / \mathrm{m}^{2} . \mathrm{K}$ & $\begin{array}{l}6.000 \\
\mathrm{~W} / \mathrm{m}^{2} . \mathrm{K}\end{array}$ \\
\hline $\begin{array}{l}\text { Proposed } \\
\text { building } \\
\text { envelope }\end{array}$ & $\begin{array}{l}\text { Cooling } \\
\text { pipes, white } \\
\text { marble finish }\end{array}$ & $\begin{array}{l}\text { Double } \\
\text { glazed dome }\end{array}$ & $\begin{array}{l}\text { Cooling pipes, } \\
\text { white marble } \\
\text { finish }\end{array}$ & $\begin{array}{l}\text { Concrete } \\
\text { blocks, Thasos } \\
\text { white marble } \\
\text { finish }\end{array}$ & $\begin{array}{l}\text { Double } \\
\text { glazed } \\
\text { aluminum } \\
\text { frame }\end{array}$ \\
\hline U-value & $\begin{array}{l}1.220 \\
\mathrm{~W} / \mathrm{m}^{2} . \mathrm{K}\end{array}$ & $\begin{array}{l}1.395 \\
\mathrm{~W} / \mathrm{m}^{2} . \mathrm{K}\end{array}$ & $1.220 \mathrm{~W} / \mathrm{m}^{2} . \mathrm{K}$ & $1.100 \mathrm{~W} / \mathrm{m}^{2} . \mathrm{K}$ & $\begin{array}{l}2.700 \\
\mathrm{~W} / \mathrm{m}^{2} . \mathrm{K}\end{array}$ \\
\hline
\end{tabular}




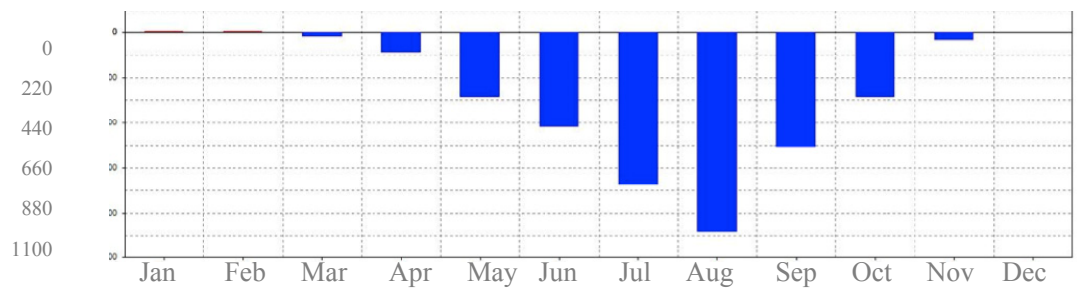

Figure 8: Existing base-case thermal analysis, monthly loads heating (red) and cooling loads (blue).

Cooling pipes are placed between flooring boards and floor slab, pipes must be attached with heat emission plates that increase the amount of heat transferred, and then covered with the floor's final covering or finishing. Based on this project, Thasos marble will be the flooring covering [7].

Stimulating and analysing the thermal envelope of existing and proposed building, using Ecotect analysis; thermal envelope and material used are calculated, including zone management schedule and amount of occupancy mentioned.

The amount of cooling needed earlier in existing design, cooling reached to an approximate of $110(11,000,000 \mathrm{~W})$, in summer season, August (as shown in figure 8$)$. While, it decreases to $440(4,400,000 \mathrm{~W})$ in proposed design, by changing its thermal envelope.

In addition to monthly analysis, figure 9 below shows hourly heat gain and loss. Red and blue colours in graph express hot and cold heat climate, while white colour shows comfort zone range. Proposed building graph reads a temperature range of 25 degrees in early morning and night, while raises through the days to reach above 35 degrees. Observing the second graph of proposed design, temperature reading is noticeable to degrees below 35 degrees.

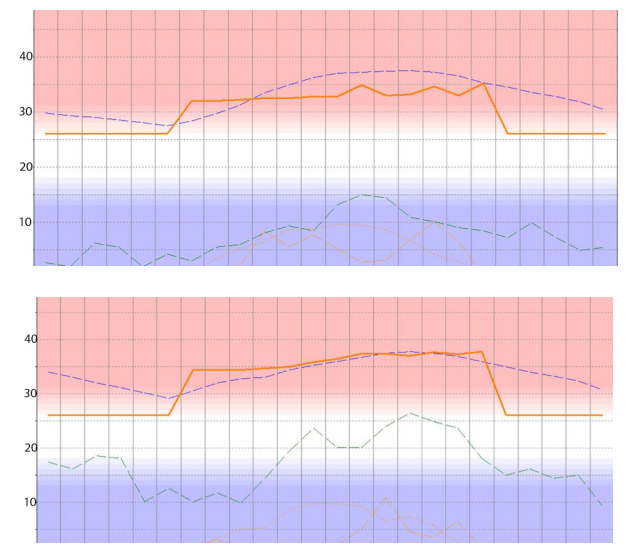

Figure 9: Existing/proposed base-case thermal analysis, hourly heat gain/loss. 


\subsubsection{Strategy 4: air movement and ventilation}

In building design, air movement is not any longer ignored by designers and architects; location and climate must be studied well and taken into consideration to enable obtain a comfortable design. Different types of air motion can be classified as forces; breezeways, wind tower, and courtyards can control air movement [8].

Focusing on the wind tower mechanism, wind is trapped down through the tower to reach lower interior spaces. Opening windows and pathways will also increase the amount of air movement in the building.
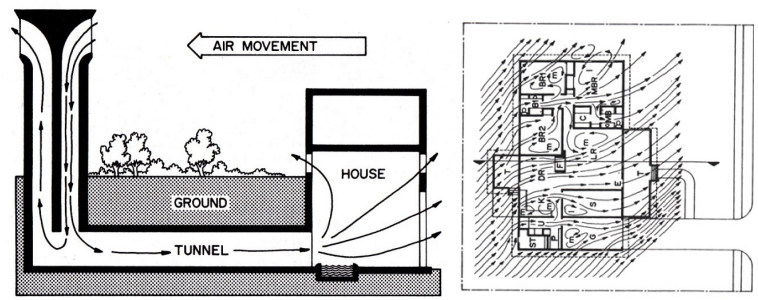

Figure 10: Air movement forces air down the wind tower/flexibility of wind tunnel studies allows for numerous variations and alternatives.

Figure 10 above describes the airflow enhanced to control air movement in the exterior to the interior areas, where air is captured from wind direction through building voids [8].

Air movement system in a building will create a passive ventilation system, helps cooling the interior and balancing it with exterior temperature.

\subsubsection{Existing building and scientific analysis of strategy 4 Existing} building consists of 4 Minaret, used as decorative elements only. Converting 3 of 4 existing minaret to wind tower will maximize passive ventilation, by achieving sufficient air flow, inspired by grapes plantation natural concept.

Calculating air flow rate:

$\boldsymbol{Q}$ (air flow) $=\boldsymbol{C} \boldsymbol{v}$ (effectiveness of opening) $\boldsymbol{x} \boldsymbol{A}$ (free air) $\boldsymbol{x} \boldsymbol{V}$ (wind velocity)

Increasing the effectiveness of opening will increase the probably of building airflow, resulting in sufficient passive airflow in building.

Inspiring from palm trees, God created trees in a special design, palm trees are narrow and leave less from the lower part to allow circulation, and dense with long leaves to divide and slow down the high wind speed. Figure 11, below, explains wind control affected by long vertical barriers inspired by palm trees. 


\subsubsection{Strategy 5: direct solar rays destitution}

6.2.5.1 Solar panels and natural concept Utilizing the existence of constant solar rays throughout the year, solar panels would be good choice to absorb rays and generate electricity per year to existing. Referencing to the day light factor initial strategy; the building was influenced by the grapes round shapes, and thus increased the number of domes and converted them to glass sky domes to enhance skylight within the building, these domes can also be used as a base for solar flexible panels. New techniques were invented to create better option to satisfy design strategies. Sphelar dome are wireless and outdoor sensing solar devices, introduced by a Japanese company in 2010. The circular shape of solar cells unlike flat solar, the spherical shape are cable more to generate better efficiency from all directions [9].

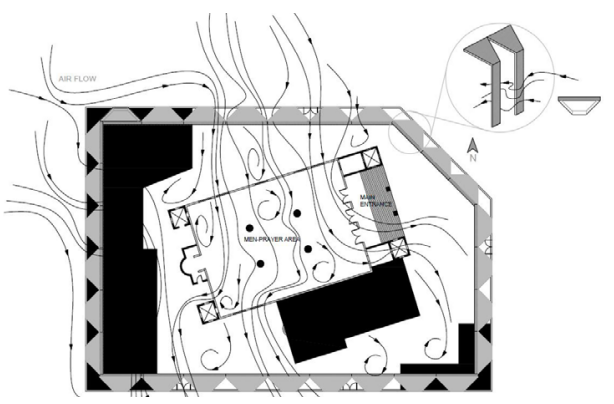

Figure 11: Wind control and ventilation, Al Ali Mosque.

6.2.5.2 Building analysis and direct solar As observed in figure 12, no direct influence on the shading devices surrounding the building, to cover direct solar rays path. Top roof if fully exposed sunlight. The usage of solar cells will work efficiently.

Figure 12 illustrates solar rays in winter (January) and summer (July) months. Where direct solar rays in winter hits at 29 degrees. While in summer direct solar rays hits in an angle of 80 degrees. Both are not affected or distracted by any surrounded elements.

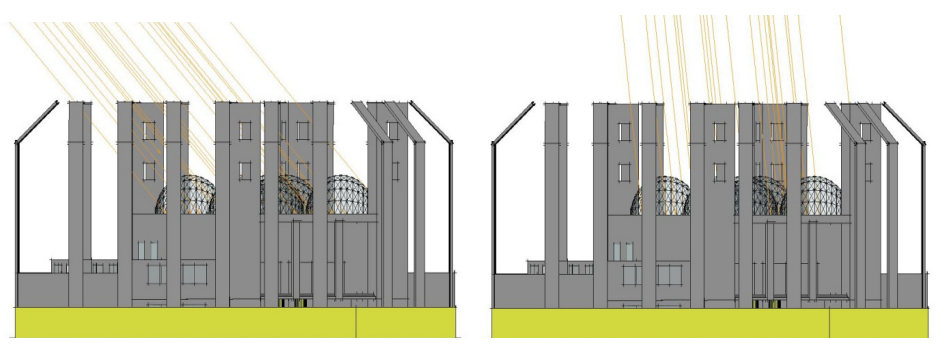

Figure 12: Winter/summer solar rays' analysis. 
6.2.5.3 Scientific comparison of strategy 5 Mosque monthly bills are an approximate average of 3,500 AED, consume of $9400 \mathrm{kWh}$ monthly.

$$
\begin{array}{r}
P V \text { Area } x \text { Inventor efficiency } \times \text { Battery efficiency } x \text { solar irradiation } \\
=(0.75 \times 1.2) \times(0.65) \times(0.70) \times(5.5)
\end{array}
$$

The proposed design, figure 13, illustrates the additional 180 solar panels needed to activate the whole mosque's electricity, 45 panels are set on wind barriers facing south on an angle of 45 degrees, 135 panels are placed on the top of men prayer area, between glass domes. In addition, 100 additional solar panels are proposed as an extra energy savings.

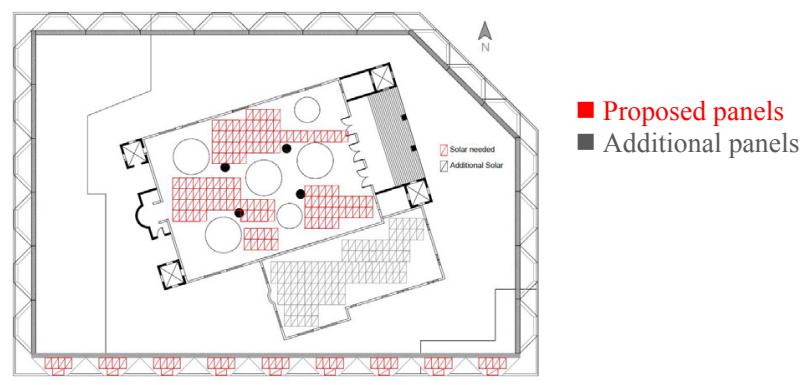

Figure 13: Solar panels, proposed (red), additional (grey), mosque roof.

\section{Design proposal}

The final design 3D proposal is illustrated in figure 14, combining 5 strategies on an existing site to produce new passive design structure.
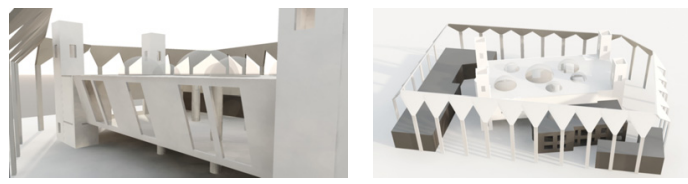

Figure 14: Proposed 3D design (authors).

\section{Conclusion}

Overall, improving design strategies may lead to a $100 \%$ passive design and will achieve sustainable environment. Design no longer resembles the dream of a caveman who longed to bring nature into his walls. It has become very complex and sophisticated matter. Different architects and psychologists through different periods in history have studied it. Some architect's defined nature as form and 
unity, as in Antonio Gaudi's designs. Frank Lloyd Wright constructed buildings in respect to nature. These architects surely influenced new generations to follow in their steps and extend nature through architecture. It can help visitors undertake the maximum function they want to do in a space. Using the elements of wind and sunlight will not only lead to a passive design but also achieve a healthier environment where the function can truly be achieved.

\section{Acknowledgement}

The authors would like to thank "MUSTADAMA Ltd. Sustainable Solutions" in Masdar City-Abu Dhabi for sponsoring this paper to be presented in the "Sustainable Development and Planning Conference" held in Istanbul in May 2015.

\section{References}

[1] Khan \& Al Hilali, The Noble Quran-In The English Language, 1996.

[2] Biomimicry, biomimicryinstitute.org

[3] Albert \& Chicago, Grapes, pp. 8-12, 1945.

[4] Al Ali Mosque Emam, 2013.

[5] AbdulKader, B., Solar panels to help cut carbon dioxide emissions, 2011.

[6] Al-Masoodi, H. \& Al-Silami, S. Heat resistant marble, Holy Haram court.

[7] CIBSE Guide B., Heating, ventilation, air conditioning and refrigeration. Composition of Grapes, pp. 1-5, 2005.

[8] Boutet S. T., Controlling Air Movement. United States America: McGrawHill Book Company, p. 70, 1987.

[9] Ebisu-cho Fushimi-ku Kyoto, Sphelar power, 2010. 